ОРГАНІЗАЦІЯ ІНТЕГРОВАНИХ ЗАНЯТЬ 3 ІНОЗЕМНОЇ МОВИ ЗА ПРОФЕСІЙНИМ СПРЯМУВАННЯМ І ТЕХНІЧНИХ ДИСЦИПЛІН В УМОВАХ ДИСТАНЦІЙНОГО НАВЧАННЯ

\title{
ORGANIZING THE INTEGRATED LESSONS IN PROFESSIONALLY - ORIENTED FOREIGN LANGUAGE WITH ENGINEERING SUBJECTS IN THE DISTANCE LEARNING TERMS
}

УДК 378.147:881.111

DOI https://doi.org/10.32843/2663-

$6085 / 2020 / 29-2.8$

\section{Малик Т.В.,}

студентка IV курсу відділення

«Насртогазова інженерія та технології» ДВНЗ «Дрогобицький коледж насти

і газу»,

студентка II курсу

Інституту іноземних мов

Дрогобицького державного

педагогічного університету

імені Івана Франка

Грицик Г.О.,

викладач іноземних мов

ДВНЗ «Дрогобицький механіко-

технологічний коледж»

Малик Л.Б.,

канд. пед. наук,

викладач загальнотехнічних дисциплін ДВНЗ «Дрогобицький коледж насти і газу»
У статті розкрито необхідність грунтовного й переосмисленого процесу забезпечення навчання $з$ вивчення іноземної мови за профресійним спрямуванням студентами технічних фрахових коледжів в умовах дистанційного навчання. Зазначено, що поглиблене вивчення іноземної мови за профресійним спрямуванням дасть змогу майбутнім фрахівцям у сфрері своєї профресійної діяльності впродовж життя самостійно поповнювати свої професійні знання, уміння й навички, ознайомлюватися із закордонним досвідом і досягненнями сучасної науки, техніки та інноваційних технологій. Виявлено, що оволодіння іноземною мовою за профресійним спрямуванням студентами технічних коледжів нафтогазового й машинобудівного профрілю не тільки розширить їхній власний світогляд і загальний інтелектуальний рівень, а й стане знаряддям, необхідним для вирішення певних профресійних проблем $і$ завдань, стане важливим і невід'ємним компонентом професійної компетентності спеціалістів, орієнтованим на особливості майбутньої просресії.

Висвітлено сучасні інноваційні підходи до питання пошуку есрективної та спеціальної методики викладання іноземних мов за професійним спрямуванням у технічних коледжах в умовах дистанційного навчання, які передбачатимуть поєднання процесів оволодіння профресійно спрямованою іноземною мовою 3 розвитком особистісних якостей студентів, знанням культури країни, мова якої вивчається, $і$ набуття спеціальних навичок, що базуються на професійних і лінгвістичних знаннях. А поєднання традиційних педагогічних та інновачійних методів навчання, а саме інтегрованих занять, іпри ї активному використанні в процесі вивчення іноземної мови за профресійним спрямуванням дасть позитивний результат у майбутній профеесійній діяльності спеціалістів. Охарактеризовано специфріку навчання іноземної мови за профресійним спрямуванням у технічних коледжах під час проведення інтегрованих занять в умовах дистаниійного навчання.

Варто підкреслити, що вільне володіння іноземною мовою за профеесійним спрямуванням дасть змогу майбутньому фрахівцю реалізувати такі плани профресійної діяльності, як ознайомлення зі світовими новітніми технологіями у сфрері науки й техніки в певній технічній галузі та досвідом їх використання, скористатися можливістю повноцінно працювати із закордонними інфрормаційними джерелами, установлювати контакти із зарубіжними партнерами в процесі професійної діяльності.

Ключові слова: іноземна мова за профресійним спрямуванням, профресійна компетент- ність, іншомовна комунікація, студент, технічний фраховий коледж, інтегроване заняття, майбутній фрахівець.

The article finds out the need for a thorough and reinterpreted process of providing training in the study of a professionally-oriented foreign language of technical college students in the terms of distance learning. It has been noted that detailed learning of a professionally-oriented foreign language will allow future specialists to extend themselves their professional knowledge, skills and abilities in the field of their future professional activity, get acquainted with foreign experience and achievements of modern science, technology and innovative technologies. It has been found that mastering a professionally-oriented foreign language by students of technical colleges of oil and gas and engineering spheres, will not only broaden their own worldview and increase general intellectual level, but also become a tool needed to solve certain professional problems and tasks, will be an important and essential component of professional competence of specialists, focused on the features of their future profession.

It has been mentioned the modern innovative approaches to the search for effective and special methods of teaching foreign languages for specific purposes in technical colleges in the terms of distance learning, which will combine the processes of mastering a professionally oriented foreign language with the development of personal qualities of students, knowledge of the culture of the country studied and gaining of special skills based on professional and linguistic knowledge. The combination of traditional pedagogical and innovative teaching methods, namely integrated lessons, and their active use in the process of learning a professionally-oriented foreign language, will give a positive result in the future professional activity of specialists. The specifics of teaching a professionallyoriented foreign language in technical colleges at integrated lessons in the terms of distance learning have been described.

It should be emphasized that fluency in a professionally-oriented foreign language will allow future specialists to implement such professional plans as acquaintance with the latest world technologies in the spheres of science and technology in a particular technical field and with experience in their use, will provide the opportunity to work with foreign information sources, to establish contacts with foreign partners in the process of professional activity. Key words: professionally-oriented foreign language, professional competence, foreign language communication, student, technical professional college, integrated lesson, future specialist. 
Постановка проблеми в загальному вигляді. У сучасному світі випереджального та прогресивного розвитку освіти, науки й техніки стає все актуальнішим розширення міжнародних освітніх та економічних зв'язків через активну співпрацю вищих фрахових технічних навчальних закладів, задля обміну науковим досвідом, спільного розроблення новітніх ідей і задумів, упровадження інноваційних технологій. Для досягнення цієї мети від представників технічних навчальних закладів різних зарубіжних країн вимагається вільне володіння хоча б однією іноземною мовою, для перспективного набуття спеціальних знань за фрахом, оскільки знання іноземної мови за професійним спрямуванням, а саме англійської мови, є найбільш розповсюдженим у близькому й далекому зарубіжжі [5, с. 15].

Вища освіта сьогодення вимагає від професійної підготовки випускників технічних коледжів глибоких професійних знань, умінь і навичок, здатності до всебічності їх застосування, ініціативності, творчості, активної комунікабельності, готовності до постійного самовдосконалення й саморозвитку. Саме вимогами до конкурентоспроможності сучасного фрахівця визначається не лише його висока кваліфікація в професійній сорері, а й здатність розв'язувати професійні завдання в умовах іншомовної комунікації. Тому останнім часом у технічних фрахових коледжах значна увага приділяється поглибленому вивченню англійської мови за професійним спрямуванням.

Аналіз останніх досліджень і публікацій, на які спирається автор, у яких розглядають цю проблему й підходи її розв'язання. Дослідженню проблем професійного навчання іноземної мови за професійним спрямуванням завжди приділялася велика увага. Зокрема, науковці досліджували такі її аспекти, як профресійна підготовка фрахівців у вищій школі (А. Алексюк, В. Козаков, В. Лазарєв, П. Підкасистий, В. Сидоренко, О. Ярошенко та ін.). Важливий науковий внесок у вивчення іноземних мов зробили О. Потебня, В. Де Соссюр, Л. Щерба. Методикою навчання іноземних мов задля професійної комунікації фрахівців з технічних спеціальностей розробляли А. Маркова, В. Александров, В. Скалкіна, В. Костомарова, О. Тарнопольський, І. Дроздова, Г. Ємельянова. Специфріку іншомовної підготовки студентів висвітлено в наукових працях таких учених нашої країни, як О. Бігич, Л. Голованчук, С. Ніколаєвої, О. Пометун, Н. Скляренко. Також результати досліджень методів навчання англійської мови висвітлені в працях зарубіжних авторів: Дж. Белла, Дж. Скрівенера, Д. Баддена, К.К. Шанка.

Виділення не вирішених раніше частин загальної проблеми. В умовах сучасних інноваційних викликів, що стоять перед вищими технічними фраховими закладами освіти, невирішених надважливих завдань професійно-орієнтованої підготовки фрахівців своєї справи постає необхідність набуття студентами спеціальних технічних компетентностей, зокрема, і в середовищі іншомовної комунікації.

Мета статті полягає в зосередженні уваги на аналізі й пошуку шляхів підвищення всебічного поглибленого навчання іноземної мови за професійним спрямуванням як ефективного та цілеспрямованого засобу успішної професійної підготовки студентів технічних фрахових коледжів.

Виклад основного матеріалу. Нові засади сучасності вимагають актуалізувати завдання забезпечення освітнього простору якісною підготовкою за відповідною профресією студентів фрахових технічних коледжів. Навчальні заклади України, які готують майбутніх фрахівців технічного спрямування, у наш час не повинні залишатися обабіч випереджального, високотехнологічного й інноваційного розвитку освіти, науки та техніки у світовому просторі.

Збільшення масштабів знань, якими повинен оволодіти майбутній фахівець нафтогазового чи машинобудівного профрілю за час навчання у фраховому коледжі, коли світовий освітній рівень вимагає підвищення якості навчання, його загальної та професійної підготовки, ставляться гострі вимоги до ретельного й усебічного дослідження системи формування в студентів спеціальних знань, умінь і навичок, пошуку як внутрішніх, так і зовнішніх чинників становлення фрахівців з вищою технічною освітою, упровадження в навчально-виховний процес особливостей профресійної підготовки на рівні технічних фрахових коледжів, оскільки від рівня профресійної підготовки фрахівців, сфрормованості його профресійних якостей значною мірою залежить успішне виконання соціального замовлення держави і світового суспільства на спеціаліста з високою професійною компетентністю [7, с. 197]. Тут варто зазначити, що світовий простір роботодавців потребує спеціаліста, який має бути не тільки творчим, ініціативним, мобільним, відзначатися своєю високоякісною кваліфрікацією в професійній сорері, а й має володіти здатністю розв'язувати професійні завдання в умовах іншомовної комунікації.

Для нашої країни процес формування професійної компетентності сучасного фрахівця $€$ дуже важливим. Ґрунтовні знання студентів у професійній сорері, їхні переконання, володіння хоча б однією іноземною мовою професійного технічного спрямування та значною мірою ціннісні орієнтації здобуваються саме під час професійного навчання, а ще в кращому випадку під час навчальних і виробничих практик у середовищі іншомовної комунікації, тобто проходження практик за кордоном. Випускник вищої школи - це фахівець, який одержав відповідну професійну підготовку, швидко орієнтується в нових сучасних ситуаціях, самостійно розв'язує професійні завдання. 
Особливого значення сьогодні набуває проблема набуття професійних компетентностей студентами технічних коледжів за допомогою засобів іншомовної комунікації. Спеціальні технічні дисципліни якнайкраще сприяють формуванню таких її елементів, як уміння планувати, раціонально організовувати та здійснювати контроль за навчальнотрудовою діяльністю, уміння технічно мислити і творчо осмислювати трудові процеси, користуватися технічними засобами та інструментами, працювати колективно, володіти іноземною мовою за профресійним спрямуванням, задля можливості надалі навчатися чи працювати за фрахом у нашій країні й за кордоном.

Формування цілісного наукового знання про техніку та технології - мета й завдання загальнотехнічної та професійної підготовки в технічних фрахових коледжах нафртогазового й машинобудівного профрілю. Даючи основу для вивчення спеціальних дисциплін, загальнотехнічні предмети піднімають поняття спецтехнології на новий теоретичний рівень [7, с. 123].

Трудова діяльність сучасної людини зводиться не тільки до фрізичної діяльності, а й усе більше до інтелектуальної. Володіння спеціальними професійними знаннями та вміннями є кінцевим результатом того процесу, який називається трудовою підготовкою особистості й здійснюється через навчання, виховання та професійний розвиток студентів, їхню навчально-пізнавальну і творчу діяльність, вивченням іноземних мов за професійним спрямуванням, що реалізується в найрізноманітніших формах педагогічного процесу в умовах дистанційного навчання через різні засоби інсрормаційно-комунікаційних технологій.

Загальновідомо, що володіння іноземною мовоюзапрофесійним спрямуванням нетільки розширює кругозір і загальний інтелектуальний рівень студента, а і $є$ інструментом, необхідним для вирішення певних професійних проблем, невід'ємним компонентом професійної компетентності майбутніх конкурентоспроможних фрахівців на ринку праці.

Проблему вивчення іноземної мови за професійним спрямуванням студентів фрахових технічних закладів освіти присвячено дуже багато наукових праць науковців, що зумовлено вимогами сучасності й роллю іноземної мови, що зростає, у просресійній діяльності майбутніх фрахівців своєї справи. Знання іноземної мови за професійним спрямуванням допомагає самостійно поповнювати професійні знання, ознайомлюватися із закордонним досвідом, досягненнями сучасної науки й техніки [6, с. 30].

Володіння іноземною мовою за професійним технічним спрямуванням дасть змогу майбутньому фахівцю реалізувати такі плани професійної діяльності, як ознайомлення 3 новими світовими дослідженнями у сорері науки й техніки, установлювати контакти із зарубіжними партне- рами в процесі професійної діяльності, знайомитися 3 науковими розробками і технологіями в певній технічній галузі та досвідом їх використання.

Профресійно спрямоване навчанням іноземної мови має бути таким, щоб у центр уваги ставилися не лише потреби студентів у вивченні іноземної мови з орієнтацією на особливості майбутньої профресії, а й розуміння та бажання оволодівати іноземною мовою як перспективою уможливлення працевлаштування на високооплачувану роботу як у нашій державі, так і за кордоном [8, с. 45].

Профресійно-спрямоване навчання має забезпечувати процес викладання іноземної мови за професійним спрямуванням, орієнтований на читання наукової та профресійно-технічної літератури відповідного технічного профрілю, вивчення професійної лексики й термінології, а в основному на спілкування у сфрері професійної діяльності.

Сучасний стан методики навчання в технічних коледжах демонструє, що викладачі змушені все активніше використовувати інноваційні методи в процесі викладання дисциплін. Намагаючись зробити заняття цікавим і зрозумілим, а засвоєння студентами інформації - швидшим і глибшим, викладачі вдаються до поєднання традиційних і новітніх методів. Сьогодні в період світового масштабу пандемії, коли використання традиційних методів є частково неможливим, викладачеві важливо правильно та доцільно організовувати навчальний процес засобами інноваційних та інтерактивних методик в умова дистанційного навчання.

Профресійно-спрямоване навчання з поглибленим вивченням іноземної мови в технічних фахових коледжах вимагає від усіх учасників освітнього процесу новітнього підходу до відбору фрорми і змісту, вибору відповідних інформаційних платформ задля забезпечення якісного навчального процесу загалом. А це, у свою чергу, вимагає від викладачів розробки нових навчальних планів, робочих програм, відповідного методичного забезпечення та інших засобів і методів інноваційного навчання.

Саме в сучасних умовах дистанційного навчання викладачам-спецпредметникам і викладачам іноземної мови потрібно постійно поглиблювати свої знання й уміння з методики викладання, удосконалювати свою роль як викладача в навчально-виховному процесі технічного фрахового коледжу, а також уносити ціннісні перспективи та методичні наробки в процес педагогічної діяльності відповідно до інтенсивного розвитку освіти, науки й техніки.

Ураховуючи специфріку профрільних спеціальностей технічних фрахових коледжів, навчання має організовуватися за певними напрямами, а самероботанадспеціальнимитехнічнимитекстами, вивчення спеціальних тем для розвитку усного мовлення, вивчення лексичного мінімуму згідно зі спеціальністю, спілкування у сорері професійної 
діяльності, створення посібників для активізації граматичного та лексичного матеріалу, організація самостійної роботи і її методичне забезпечення, створення навчальних комплексів фрахового спрямування відповідно до вимог сучасного суспільства в умовах дистанційного навчання [6, с. 28].

Аналізуючи процес вивчення іноземної мову як засобу фрормування професійних компетентностей майбутнього фахівця, науковець Н. Гальськова зазначає, що при вивченні навчального матеріалу профресійних дисциплін разом із іноземною мовою встановлюються ніби двосторонні взаємозв'язки між прагненням студента здобути спеціальні фахові знання й успішним оволодінням іноземною мовою за професійним спрямуванням. На її думку, у зміст вивчення іноземної мови варто включити комплекс спеціальних (мовних) умінь, мовний матеріал (граматичний, лексичний, фонетичний, орфографічний), правила оформлення та навички оперування; сфери комунікативної діяльності, мовні дії й мовленнєвий матеріал, теми й ситуації; систему знань національно-культурних особливостей і реалій країни, мова якої вивчається [2, с. 4-7].

Сучасні перспективи пошуку універсальної методики викладання іноземних мов у технічних фрахових коледжах полягає в поєднанні традиційних, інноваційних та інтерактивних методів, засобів і фрорм навчання. Активне використання сучасних новітніх технологій у процесі навчання іноземної мови за професійним спрямуванням в умовах дистанційного навчання дає позитивний результат на засвоєння та використання іноземної мови майбутніми спеціалістами технічного профрілю в професійній діяльності [3, с. 21].

Упровадження сучасних інформаційно-комунікаційних технологій, як засвідчує український і зарубіжний досвід, в освітній процес вищих технічних навчальних закладів $€$ підґрунтям забезпечення есрективного навчання за можливості підвищення рівня поінорормованості, інтерактивності й інновацій використання інформаційно-комунікаційних Інтернет ресурсів, навчально-електронних засобів, електронних навчальних бібліотек та автоматизованих систем керування освітньою діяльністю.

Аналіз роботи багатьох технічних фрахових коледжів у необхідності розробки й застосування інтерактивних методик в умовах дистанційного навчання показує, що робота викладачів за допомогою інформаційно-комунікаційних освітніх технологій, застосування ними електронних навчальних платфрорм не може відбуватися без поінорормованості учасників освітньої діяльності, автоматизації освітньої діяльності, формування новаційного освітнього інтерактивного навчання, застосування всіх можливостей електронного навчання та отримання затребуваної інфрормації, потрібної для забезпечення мети освітньої діяльності, доцільності використання засобів інфрормаційних технологій (Інтернет-ресурси, інформаційнокомп'ютерних технологій, навчальних Інтернетплаторорм, електронної пошти тощо) [9, с. 6-8].

У нашому освітньому просторі й за кордоном розроблені відповідні платформи для проведення дистанційного навчання, які базуються на активному використанні інформаційно-комунікаційних технологій. I пріоритетним уважаємо напрям підвищення якості дистанційного навчання, що передбачає розробку нових інтерактивних он-лайн-курсів, їх адміністрування та підтримку. А в інтерактивних комунікаціях не можна обійтися без засобів інтерактивної взаємодії, а саме ноутбуків, смартфонів, планшетів, інформаційних програм і платорорм, електронних книг, мультимедійних пристроїв та інтерактивних дощок.

Навчальна робота, яка здійснюється двома й більше викладачами-спецпредметниками та викладачами іноземних мов у груповій формі, як основа в технології інтерактивного навчання не ізолює студентів один від одного, а дає можливість реалізовувати свої природні прагнення до комунікації, взаємодії та співпраці, фрормує вміння відстоювати власну думку, бути експертом у проблемних питаннях навчальних завдань, професійного навчання [8, с. 27].

Дистанційне навчання за умови правильної його організації й застосування стає великим простором можливостей для отримання певних професійних знань і вмінь за певним профілем, яке здійснюється за допомогою сучасних технологій, що дають можливість отримати навчальну спеціальну інформацію за допомогою інформаційнокомунікаційних технологій від тих, хто вчить, до тих, хто навчається, а саме студентів.

Основними принципами дистанційного навчання в дослідженні $є$ інтерактивна взаємодія в навчальному процесі, надання студентам можливості самостійної роботи з освоєння навчального матеріалу, а також консультаційний супровід у процесі дослідницької діяльності.

Моделі навчального процесу в технічних коледжах будуються на основі багатокомпонентного варіативного змісту освіти. Науковці та практики професійного навчання постійно шукають нові методи вдосконалення навчально-виховного процесу, що сприяли б творчому самовираженню студентів, особистісно-ціннісному ставленню студентів до свого навчання, умінню виконувати творчі завдання тощо. Таким забезпеченням освітнього процесу $є$ проведення інтегрованих занять, відібраного з кількох предметів та об'єднаного навколо однієї мети, а саме загальнотехнічних, спеціальних професійних дисциплін та іноземних мов за професійним спрямуванням. Такий підхід сприяє інорормаційному збагаченню технічного мислення студентів завдяки використанню цікавого творчого 
навчального матеріалу, що дало б змогу всебічно пізнати якісь явища, процеси й технології, досягти цілісності знань [1, с. 56].

Використання інтерактивних методів навчання дає змогу реалізувати ідею якісної співпраці викладачів спеціальних дисциплін і викладачів іноземних мов зі студентами, реалізовує їх конструктивні взаємодії, сприяє покращенню засвоєнню спеціальних технічних навчальних матеріалів 3 одночасним вивченням іноземної мови за професійним спрямуванням, спонукає до створення доброзичливої атмосфери, як результат, зможе значно підвищити мотивацію студентів до навчання.

Уведення в педагогічну практику в умовах дистанційного навчання інтегрованих занять має здійснюватися за умови перебудови та переформатування процесу навчання.

Відмінність інтегрованого уроку від традиційного в умовах дистанційного навчання буде полягати саме в тому, що для вивчення навчального матеріалу на такому занятті будуть виступати різноманітні навчальні об'єкти, інформація, яка міститься в різних навчальних дисциплінах; широка можливість використання міжпредметних зв'язків, методи, прийоми та форми, які сприятимуть його організації й реалізації поставлених завдань.

Проведення інтегрованих занять має на меті об'єднувати знання 3 різних навчальних дисциплін, навчальних тем навколо однієї проблеми, задля інорормаційного та емоційного збагачення творчого мислення, сприймання, що дасть змогу пізнавати певне явище різнобічно, досягати цілісності знань і вмінь.

Тут варто зазначити, що педагогічною умовою забезпечення процесу навчання в умовах дистанційного навчання та організації проведення інтегрованого заняття для викладачів спеціальних дисциплін технічного профрілю й викладачів іноземної мови за профресійним спрямуванням $€$ розроблення спеціальним навчальних методик, навчальних програм, а також відповідного методичного забезпечення, пізнавальних і практичних завдань для творчого й самостійного опрацювання студентами.

Під час проведення інтегрованих занять у технічних коледжах в умовах дистанційного навчання доцільне використання ілюстрацій, демонстрацій, презентацій, відеороликів, інтерактивних порівняльних таблиць, у процесі вивчення технічного навчального матеріалу англійською мовою за допомогою інфрормаційно-комунікаційних технологій задля забезпечення якісного, доступного, зрозумілого та поглибленого забезпечення навчального процесу.

Розглядаючи вищесказане, згідно 3 власним досвідом викладання іноземної мови за професійним спрямуванням, як приклад ми можемо запропонувати фррагмент методичного забезпечення уроку, який містить тест профресійного спрямування та комплекс лексичних вправ, спрямованих на опрацювання й засвоєння фахової термінології та автоматизацію навичок уживання лексико-граматичних конструкцій:

Read and translate the text using the active vocabulary:

\section{Exploration drilling}

Once a promising geological structure has been identified, the only way to confirm the presence of hydrocarbons and the thickness and internal pressure of a reservoir is to drill exploratory boreholes. All wells that are drilled to discover hydrocarbons are called 'exploration' wells, commonly known by drillers as 'wildcats'. The location of a drill site depends on the characteristics of the underlying geological formations. A pad for a single exploration well occupies between 4000-15000 m2. The type of pad construction depends on terrain, soil conditions and seasonal constraints. Operations over water can be conducted using a variety of self-contained mobile offshore drilling units (MODUs).

Land-based drilling rigs and support equipment are normally split into modules to make them easier to move.

Typical drilling rig modules include a derrick, drilling mud handling equipment, power generators, cementing equipment and tanks for fuel and water (see Figure 2).

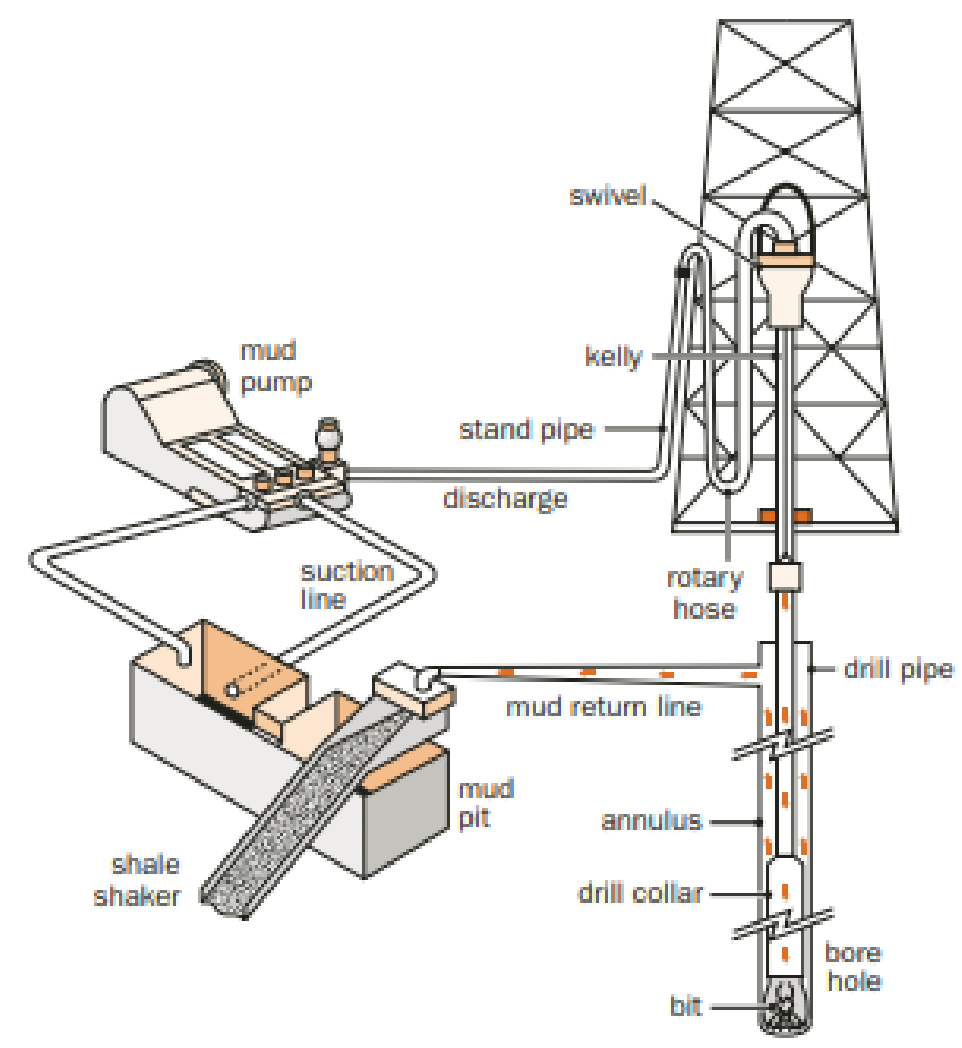

Figure 2. Drilling 
Once drilling commences, drilling fluid or mud is continuously circulated down the drill pipe and back to the surface equipment. Its purpose is to balance underground hydrostatic pressure, cool the bit and flush out rock cuttings. The risk of an uncontrolled flow from the reservoir to the surface is greatly reduced by using blowout preventers - a series of hydraulically actuated steel rams that can close quickly around the drill string or casing to seal off a well. Steel casing is run into completed sections of the borehole and cemented into place. The casing provides structural support to maintain the integrity of the borehole and isolates underground formations. Drilling operations are generally conducted around-the clock. The time taken to drill a bore hole depends on the depth of the hydrocarbon bearing formation and the geological conditions. Where a hydrocarbon formation is found, initial well tests are conducted to establish flow rates and formation pressure. After drilling and initial testing, the rig is usually dismantled and moved to the next site.

\begin{tabular}{|c|c|}
\hline \multicolumn{2}{|c|}{ Active Vocabulary: } \\
\hline $\begin{array}{l}\text { exploration drilling - роз- } \\
\text { відувальне буріння } \\
\text { hydrocarbons - вуглеводні } \\
\text { internal pressure - вну- } \\
\text { трішній тиск } \\
\text { reservoir - резервуар } \\
\text { 'exploration' } \\
\text { well/'wildcat'- розвід- } \\
\text { увальна свердловина } \\
\text { drilling unit - бурова уста- } \\
\text { новка } \\
\text { a derrick - вишка } \\
\text { drilling mud I fluid - буро- } \\
\text { вий розчин } \\
\text { tanks for fuel and water - } \\
\text { бак для палива й води } \\
\text { swivel - вертлюг } \\
\text { kelly - робоча або ведуча } \\
\text { труба, квадрат } \\
\text { mud pump - шламовий } \\
\text { насос } \\
\text { drill collar - мусрта }\end{array}$ & $\begin{array}{l}\text { stand pipe - стояк } \\
\text { discharge - вихід/стік } \\
\text { suction line - всмокту- } \\
\text { вальна труба } \\
\text { rotary hose - ротаційний } \\
\text { рукав/шланг } \\
\text { drill pipe - бурова труба } \\
\text { shale shaker - вібра- } \\
\text { ційне сито } \\
\text { mud pit - відстійник } \\
\text { annulus - затрубний про- } \\
\text { стір } \\
\text { a well/bore hole - сверд- } \\
\text { ловина } \\
\text { bit - долото } \\
\text { to flush оut - продувати/ } \\
\text { вимивати струменем } \\
\text { рідини } \\
\text { to seal off - герметично } \\
\text { запаювати } \\
\text { a rig - бурова установка }\end{array}$ \\
\hline
\end{tabular}

\section{Vocabulary exercises}

\section{l. Answer the following questions:}

1. What is called 'exploration' well?

2. What does the location of a drill site depend on?

3. What do typical drilling rig modules include?

4. With what purpose is drilling fluid continuously circulated down the drill pipe and back to the surface equipment?

5. What does the time taken to drill a bore hole depend on?

II. Complete the following sentences according to the content of the text:

1. The only way to confirm the presence of hydrocarbons is ...

2. ... are usually called 'wildcats'.

3. The type of pad construction depends on ...
4. Self-contained mobile offshore drilling units are used for ...

5. The risk of an uncontrolled flow from the reservoir to the surface is greatly reduced by ...

III. Match the following words in A with their definitions in B:

\begin{tabular}{|l|l|}
\hline \multicolumn{1}{|c|}{ A } & \multicolumn{1}{c|}{ B } \\
\hline a pump & a tall structure over an oil well for holding the drill \\
\hline \multirow{3}{*}{ a bit } & $\begin{array}{l}\text { a large piece of equipment that is used for } \\
\text { taking oil or gas from }\end{array}$ \\
\cline { 2 - 3 } & the ground or the bottom of the sea \\
\hline wel & a tube through which liquids and gases can flow \\
\hline a rig & a deep hole in the ground \\
\hline a pipe & $\begin{array}{l}\text { machine that is used to force liquid, gas or air } \\
\text { into or out of sth }\end{array}$ \\
\hline a derrick & a tool or part of a tool for making holes \\
\hline
\end{tabular}

Ще наведемо фррагмент методичного забезпечення для інтегрованого заняття 3 англійської мови за професійним спрямуванням і дисциплін загальнотехнічного циклу [10], яким можна користуватися в умовах дистанційного навчання:

\begin{tabular}{l|l|}
\hline \multicolumn{1}{|c|}{ Learn the following words and word combinations: } \\
\hline endurance strength - межа & an endurance limit - \\
зносостійкості & граничний розмір \\
fatigue loads - втомне наван- & міцності \\
таження & heat-treated alloy \\
carbon steel - вуглецева сталь & steel - термічно \\
failure - пошкодження & оброблена легована \\
wrought steel - кована сталь & сталь \\
nonferrous metals - кольорові & medium-carbon \\
метали & steel - середньову- \\
alloy - сплав & глецева сталь \\
\hline
\end{tabular}

\section{Endurance strength}

The endurance strength of a material is its ability to withstand fatigue loads. In general, it is the stress level that a material can survive for a given number of cycles of loading. If the number of cycles is infinite, the stress level is called the endurance limit $\sigma_{R}$.

Endurance strengths are usually charted on a graph like that shown in Figure 3.5, called an S-N diagram.

Curves $A, B$ and $D$ are representative of a material that does exhibit an endurance limit, such as plain carbon steel. Curve $\mathrm{C}$ is typical of most nonferrous metals, such as aluminum, which do not exhibit an

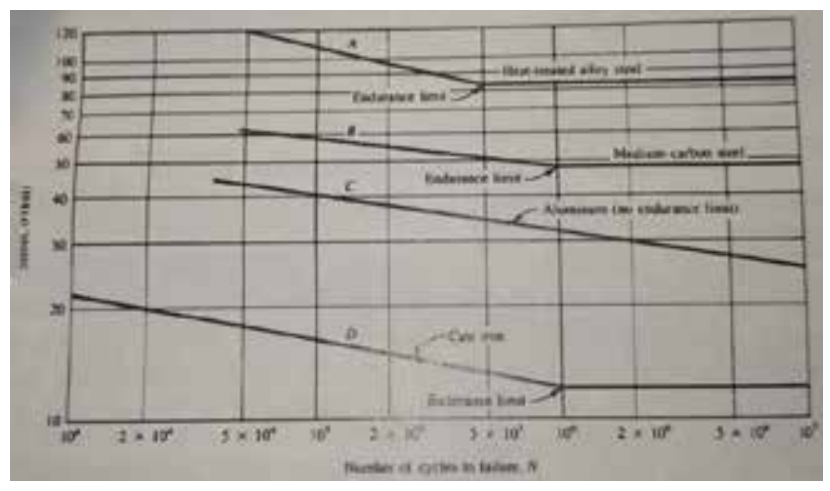

Figure 3.5. Representative endurance strengths 
endurance limit. For such materials, the number of cycles to failure should be reported for the given endurance strength.

Data for the endurance strength of the specific material for a part should be used whenever it is available, either from test results or from reliable published data. However, such data are not always readily available. The basic endurance strength for wrought steel: $\sigma_{\mathrm{R}=0,5} \sigma_{\mathrm{u}}$

\section{Answer the following questions:}

1. What is the endurance strength of materials?

2. What is shown in Figure 3.5?

3. What is the basic endurance strength for wrought steel?

Use words in the box to complete the sentences:

carbon steel // medium carbon steels //
non-ferrous metal // ferrous metal //
endurance strength // endurance limit

1. ... is defined as the maximum value of completely reversed bending stress that a material can withstand for a finite number of cycles without a fatigue failure.

2. ... is a metal, including alloys, that does not contain iron.

3. ... are quite often hardened and tempered using heat treatment.

4. ... is the stress level below which an infinite number of loading cycles can be applied to a material without causing fatigue failure.

5. ... is a metal, including alloys, that contains iron.

6. ... is a combination of two elements, iron and carbon.

Висновки. Отже, викладачам іноземної мови за професійним спрямуванням разом із викладачами загальнотехнічних і спеціальних дисциплін необхідно вдосконалювати й підвищувати якість викладання іноземної мови за професійним спрямуванням у технічному коледжі, ураховувати специфіку вивчення технічних профрільних дисциплін і майбутньої профессійної діяльності, потрібно систематично використовувати як традиційні методи навчання, так і в поєднанні 3 новітніми інтегра- ційними та інформаційно-комунікаційними технологіями в умовах дистанційного навчання. Така організація освітнього процесу дасть змогу підготувати вмотивованого, професійно компетентного фрахівця зі знанням іншомовної комунікації своєї професії, який буде мобільним, здатним жити, працювати й навчатися протягом життя в постійно змінному середовищі освіти, науки й техніки як у нашій країні, так і за кордоном.

\section{БІБЛІОГРАФІЧНИЙ СПИСОК:}

1. Андрєєв М. Інтегративні тенденції в навчанні. Софія : Народна просвіта, 1986. 176 с.

2. Гальскова Н.Д. Современная методика обучения иностранному языку : пособие для учителя. Москва : АРКТИ-Глосса, 2000. 165 с.

3. Гончаренко С.У., Мальований Ю.І. Інтегроване навчання. За і проти. Освіта. 1994. № 15.

4. Грицик Г.О. Англійська мова. Обслуговування систем управління та автоматики : збірник вправ для студентів спеціальності. Дрогобич : Видавничий центр ДМТК, 2018. 72 с.

5. Зязюн І.А. Концептуальні засади теорії освіти в Україні. Педагогіка $і$ освіти. 2000. № 1. С. 11-24.

6. Ляховицкий М.В. О некоторых базисных категориях методики обучения иностранным языкам. Иностранные языки в школе. 1973. № 1. C. 27-34.

7. Малик Л.Б. Культура праці студентів технічних коледжів як важлива складова навчальної та трудової діяльності майбутніх фрахівців. Проблеми сучасної педагогічної освіти. Серія «Педагогіка і психологія» : збірник статей. Ялта : РВВ КГУ, 2014. Вип. 43. 4. 2. C. $195-203$.

8. Образцов П.И., Иванова О.Ю. Просрессионально-ориентированное обучение иностранному языку на неязыковых фракультетах вузов. Орел : ОГУ, 2005. $114 \mathrm{C}$.

9. Шпонтак І.М. Використання інтерактивних комп'ютерних технологій у навчально-виховному процесі як цілісний творчий підхід щодо формування майбутнього фахівця. Безпека життєдіяльності. 2010. № 12. C. 6 -8.

10. Petryna D., Yakym R. Mechanics of machines. Ivano-Frankivsk, 2016. 189 p. 